\title{
SISTEM PENGONTROL SUHU PADA ALAT PENGERING KOPRA DENGAN METODE PID
}

\author{
Anton $^{1}$, Ifni Joi ${ }^{2}$, Rival Syafriwandi ${ }^{3}$ \\ 123 Jurusan TeknikElektroPoliteknikNegeri Padang \\ anton@pnp.ac.id \\ Kampus Politeknik Negeri Padang, Limau Manis Padang
}

\begin{abstract}
The design of copra dryers is one of the processes in processing copra into oil. So it takes an automatic dryer. Basically this dryer is a heating device that works based on the setpoint that has been given. The temperature detection parameters use the DHT11 sensor and the humidity level is detected using the DHT11 sensor then the temperature and humidity data will be displayed on the LCD display. Using proportional, proportional-integral and proportional-derivative controls system instability occurs so that control is used simultaneously with proportionalintegral-derivative . All instructions for running this tool are in the Arduino uno microcontroller with the PID method as the main controller. The parameters obtained for $\mathrm{PID}$ control are $\mathrm{Kp}=24,936 \mathrm{Ti}=60$ and $\mathrm{Td}=15$. The heat source is generated by the heating element (Heater) to deliver the heat energy to the copra in the drying box. The DHT11 sensor will detect the room temperature on the drying box. The DHT11 sensor can measure the temperature of the dryer with a level of accuracy almost similar to the thermometer, based on testing the average error obtained is $1.42 \%$. To reach 7\% humidity in this dryer it takes a drying time of 690 minutes.
\end{abstract}

Keywords: Arduino uno, DHT11 sensor, heater, PID, LCD

\begin{abstract}
Abstrak - Rancang bangun alat pengering kopra merupakan salah satu proses dalam pengolahan kopra menjadi minyak. Sehingga dibutuhkan sebuah alat pengering otomatis. Pada dasarnya alat pengering ini adalah sebuah alat pemanas yang sistem kerjanya berdasarkan setpoint yang telah diberikan. Parameter pendeteksian suhunya menggunakan sensor DHT11 dan tingkat kelembabannya dideteksi menggunakan sensor DHT11 kemudian data suhu dan kelembabannya akan ditampilkan pada LCD display.Dengan menggunakan kontrol proportional, proportionalintegral dan proportional-derivative terjadi ketidakstabilan sistem sehingga digunakanlah pengontrolan secara bersamaan dengan proportional-integral-derivative. Semua instruksi untuk menjalankan alat ini terdapat pada mikrokontroller Arduino uno dengan metoda PID sebagai pengendali utama. Parameter yang didapatkan untuk pengendalian PID adalah $\mathrm{Kp}=24.936 \mathrm{Ti}=60$ dan $\mathrm{Td}=15$. Sumber panasnya dihasilkan oleh elemen pemanas $(\mathrm{Heater})$ untuk menghantarkan energi panas tersebut terhadap kopra yang ada dalam box pengeringan. Sensor DHT11 akan mendeteksi suhu ruangan pada box pengeringan.Sensor DHT11 dapat mengukur suhu alat pengering dengan tingkat ketelitian hampir mirip dengan alat ukur suhu thermometer, berdasarkan pengujian rata-rata error yang didapat sebesar $1.42 \%$. Untuk mencapai kelembaban $7 \%$ di dalam alat pengering ini dibutuhkan waktu pengeringan selama 690 menit.
\end{abstract}

Kata kunci: Mikrokontroller Arduino uno, sensor DHT11, Heater, Metoda PID, LCD.

(C) 2019 Elektron Jurnal Ilmiah

\section{PENDAHULUAN}

Tanaman kelapa (Cocos nucifera L) merupakan salah satu penghasil bahan makanan yang sangat penting dalam kehidupan rakyat Indonesia. Hal ini dapat dilihat dari kenyataan bahwa $75 \%$ dari minyak nabati dan $8 \%$ dari komsumsi protein bersumber dari kelapa. Selain itu tanaman kelapa merupakan tanaman serbaguna, yang keseluruhan bagiannya dapat dimanfaatkan bagi kehidupan manusia dan menghasilkan keuntungan. Kendala yang ditemukan adalah kualitas minyak industri rakyat sangat rendah karena kopra sebagai bahan bakunya berkualitas rendah dan mempunyai kadar air tinggi'[1].

Hal tersebut sangat memungkinkan karena proses produksi kopra dari tanaman kelapa dapat dilakukan dalam lingkup usaha mikro dengan peralatan dan perlengkapan yang mudah diperoleh, mengingat dari aspek kebutuhan akan kopra sangat dibutuhkan industri seperti minyak nabati dan kebutuhan rumah tangga.[6].

Hasil pengamatan dilapangan proses pengeringan kopra yang dilakukan oleh industri rakyat selama ini adalah dengan cara konvensional yaitu, dikeringkan dengan cahaya matahari dilapangan dan menggunakan tungku pemanas dengan pemanasan langsung dengan bahan bakarnya dari kayu atau batok kelapa. Kedua proses pengeringan ini mempunyai kelemahan antara lain pengeringan dengan sinar matahari langsung dilapangan mengasilkan kopra yang terkontaminasi dengan debu-debu dan mikroba sehingga berjamur, disamping itu proses pengeringan yang tidak maksimal mengakibatkan kopra yang dihasilkan mempunyai kadar air yang tinggi,dan 
dengan menggunakan tungku pemanas mengakibatkan temperatur/suhu pemanasan tidak dapat ditentukan dengan pasti sehingga temperatur tinggi tidak dapat dikontrol dan akibatnya ada bagian sel yang mengeras akibat proses pengeringan kopra yang tidak sempurna [3]. Oleh karena itu dibuatlah suatu alat untuk mempermudah industri mikro untuk melakukan proses pengeringan kopra secara cepat untuk menghasilkan pengeringan kopra secara maksimal dan tidak bergantung pada sinar matahari langsung

Dengan seiringnya perkembangan teknologi dan peralatan-peralatan canggih yang dapat dioperasikan dengan otomatis, maka didapatlah solusi untuk mengatasi masalah tersebut dengan mengganti sistem konvensional dengan menggunakan alat pengeringan kopra berdasarkan temperatur pengolahannya.

Alat pengeringan kopra ini merupakan alat yang dapat dioperasikan dengan memanaskan kopra menggunakan listrik. Alat ini dilengkapi dengan heater sebagai pemanas dalam proses pengeringan kopra, fan yang digunakan sebagai penstabil panas yang dihasilkan heater, dan sensor thermal untuk mendeteksi suhu proses pasteurisasi. Untuk dapat mengetahui suhu saat proses pengeringan berlangsung, digunakan sensor thermal type DHT11. Pembacaan suhu pada sensor DHT11 di monitoring dengan menggunakan tampilan LCD, yang dapat dilihat langsung besaran suhu saat proses pengeringan berlangsung. Seluruh sistem tersebut dapat dikendalikan dengan menggunakan mikrokontroler Arduino.

\section{METODE PENELITIAN}

Penelitian untuk perancangan alat pengering kopra ini dibuat berdasarkan blok diagram berikut:

\section{A. Blok Diagram Kendali Suhu}

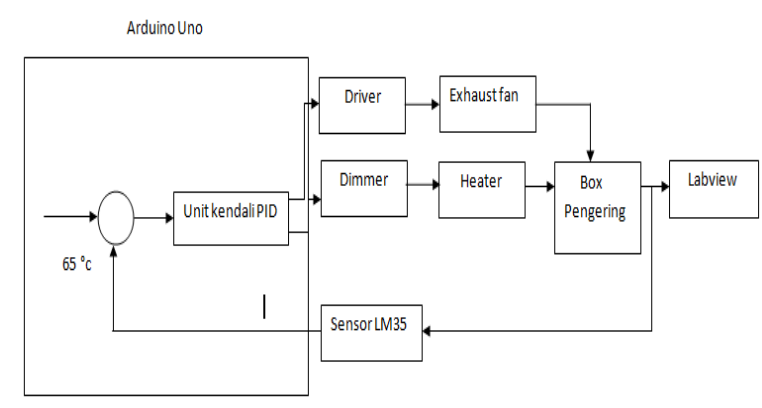

Gambar 1. Blok diagram kendali suhu

Berdasarkan blok diagram kendali suhu di atas maka dapat diketahui prinsip kerja alat pengering kopra ini melalui 3 tahap yaitu input, proses dan output. Arduino Uno sebagai proses pengendalian yang akan mengontrol heater. Pengontrolan heater menggunakan pengaturan pwm pada relay. Saat alat telah di hidupkan maka pwm akan di setting $100 \%$ sehingga nilai suhu yang terukur mencapai setpoint. Apabila suhu telah terukur $58^{\circ} \mathrm{C}$ oleh sensor DHT11 maka exhaust fan akan aktif dan membuang panas yang terdapat pada box pengering, kondisi tersebut akan terus berjalan sehingga panas pada box pengering stabil di $58^{\circ} \mathrm{C}$. Kemudian LCD akan menampilkan data yang terukur oleh sensor DHT11.

\section{B. Blok Diagram Kendali Kelembaban}

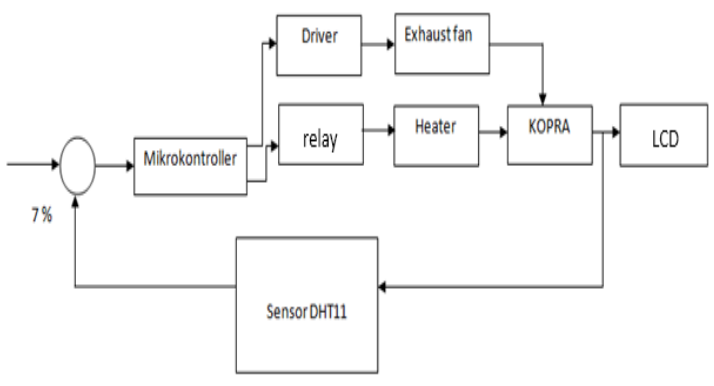

Gambar 2. Blok diagram kendali kelembaban

Berdasarkan blok diagram kendali kelembapan di atas bisa diketahui bahwa prinsip kerja alat ini melalui tahapan utama berupa input, proses dan output. Setpoint yang berupa input diberikan pada sistem pengendalian adalah 7\% yang berarti sistem akan berhenti bekerja apabila kelembapan telah mencapai $7 \%$. Mikrokontroler arduino uno sebagai proses pengolahan data akan mengontrol output pada sistem pengendalian ini, exhaust fan dan heater akan terus aktif. Semua sistem akan terhenti ketika sensor membaca data sebesar 7\%. Data pada pembacaan sensor akan ditampilkan pada LCD.

Prinsip kerja dari pengering kopra ini melalui 3 tahapan utama yaitu proses input, proses pengolahan data dan output. Proses input berupa suhu dan kelembaban dari ruang sekitar kopra yang diukur dengan menggunakan 1 buah sensor DHT11 untuk mengukur suhu dan 2 buah sensor DHT11 untuk mengukur kelembapan. Kemudian pengolahan data menggunakan mikrokontroler arduino uno dengan mengatur setpoint yang diinginkan dari input untuk menghasilkan respon plant atau output berupa heater dan exhaust fan. Saat daya telah dihidupkan maka sensor akan mengukur suhu di ruang box pengering dan kelembaban yang terdapat pada kopra kemudian menampilkannya pada lcd. Lalu mengaktifkan heater sesuai dengan data yang telah dimasukkan pada pengontrolan. Heater akan terus aktif untuk mencapai suhu $58^{\circ} \mathrm{C}$ dan exhaust fan akan mensirkulasi udara panas keluar dari box pengeringan apabila suhu melebihi setpoint yang diberikan sehingga suhu tetap dalam keadaan normal $58^{\circ} \mathrm{C}$. Selanjutnya jika kelembaban disekitar ruang kopra telah mencapai sekitar 7\% maka alat akan berhenti dengan mematikan exhaust fan dan heater. Jika hasil yang diinginkan 
belum tercapai maka alat akan terus hidup hingga kelembaban tercapai.

\section{HASIL DAN PEMBAHASAN}

Sistem pengontrolan alat ini menggunakan mikrokontroler arduino uno dengan metoda PID. Sistem kontrol PID terdiri dari tiga buah cara pengaturan yaitu P (Proportional), I (Integral) dan D (Derivative), masing-masing cara tersebut memiliki kelebihan dan kekurangan sehingga untuk menghasilkan sistem yang lebih efisien dan baik maka ketiga pengaturan tersebut digabungkan menjadi satu kesatuan. Dalam implementasinya pengontrolan PID ini bisa bekerja secara gabungan maupun bekerja sendiri. Sebelum pengontrolan dapat dilakukan maka yang perlu dilakukan terlebih dahulu adalah menemukan parameter $\mathrm{P}, \mathrm{I}$ dan $\mathrm{D}$ dengan menggunakan cara tuning langsung yaitu dengan metoda zigler-nichols. Hal pertama yang perlu dilakukan untuk mendapatkan parameter P, I dan D adalah mencari respon dari alat pengering kopra tersebut, dalam hal ini respon dilihat dari suhu pada box pengeringan terhadap waktu. Respon dilihat dari respon waktu awal suhu dan wak tu naik suhu hingga suhu maksimal yang bisa dicapai oleh heater. Berdasarkan data respon alat tersebut dapat ditentukan nilai $\mathrm{L}$ dan $\mathrm{T}$ untuk mendapatkan parameter $\mathrm{Kp}$, Ki dan Kd sebagai penyusun kontrol PID. Berikut grafik perubahan suhu yang didapatkan dari pengujian heater :

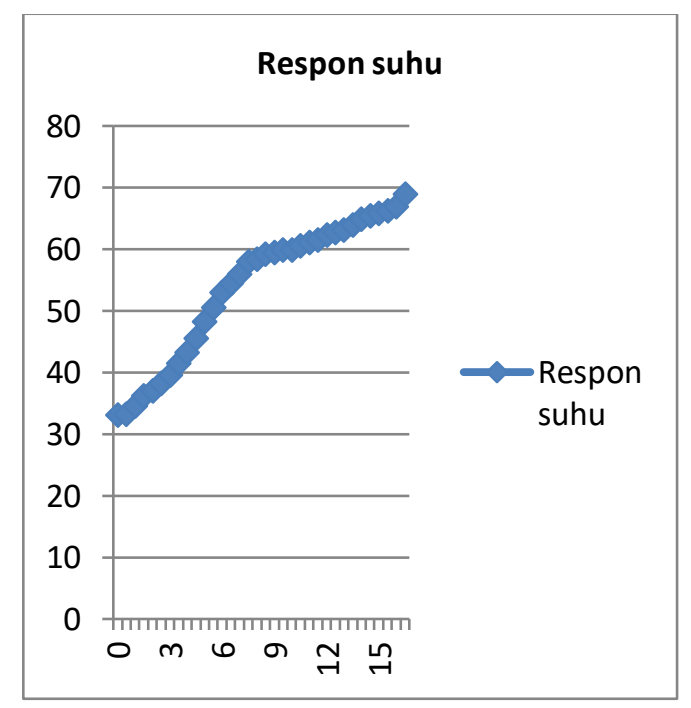

Gambar 3. Grafik respon suhu terhadap waktu pemanasan heater

Dari grafik di atas didapatkan nilai $\mathrm{L}$ dan $\mathrm{T}$ dengan metoda zigler-nichols yaitu metoda kurva reaksi, nilai L yang didapatkan berdasar grafik di atas adalah 30 dan nilai $T$ yang didapatkan adalah 623,4. Setelah didapatkan nilai $\mathrm{L}$ dan $\mathrm{T}$ maka cari nilai $\mathrm{Kp}$, $\mathrm{Ki}$ dan $\mathrm{Kd}$ dengan memasukkannya ke dalam rumus yang ada. Rumus untuk mencari nilai konstatnta proportional, konstanta integral dan konstanta derivative yaitu : $\mathrm{Kp}=$ $1 / 2 \mathrm{~T} / \mathrm{L}, \mathrm{Ti}=2 \mathrm{~L}, \mathrm{Td}=0.5 \mathrm{~L}$.
Hasil dari pencarian konstanta proportional, konstanta integral dan konstanta derivative dapat dilihat pada tabel 1 .

Tabel 1. Parameter PID dengan metoda kurva reaksi zigler-nichols

\begin{tabular}{ccccc}
\hline No & Kontrol & $\mathrm{Kp}$ & $\mathrm{Ti}$ & $\mathrm{Td}$ \\
\hline 1 & $\mathrm{P}$ & $623,4 / 30=$ & $\infty$ & 0 \\
& & 20,78 & & \\
\hline 2 & PI & $\begin{array}{c}0.9 \times 20,78= \\
18,702\end{array}$ & $\begin{array}{c}30 / 0,3= \\
100\end{array}$ \\
& \multicolumn{1}{c}{$\begin{array}{c}1.2 \times 20,78= \\
24,936\end{array}$} & $2 \times 30=60$ & $\begin{array}{c}0.5 \times 30 \\
=15\end{array}$ \\
\hline 3 & PID & &
\end{tabular}

Dari tabel di atas didapatkan parameter PID untuk pengontrolan heater pada alat pengering kopra ini yaitu $\mathrm{Kp}=24,936 \mathrm{Ti}=60 \mathrm{Td}=15$. Dimana $\mathrm{Ki}=\mathrm{Kp} / \mathrm{Ti}$ dan $\mathrm{Kd}=\mathrm{Kp} \times \mathrm{Td}$ sehingga $\mathrm{Ki}=24,936 / 60=0,4156$ dan $\mathrm{Kd}=24,936 \times 15=374,04$.

Hasil pengujian kerja alat pengering kopra dengan nilai parameter pengendali PID yang telah didapatkan diatas ditulis dalam tabel 2 .

Tabel 2. Hasil pengujian alat pengering kopra

\begin{tabular}{|c|c|c|c|c|c|}
\hline $\begin{array}{c}\text { Waktu } \\
\text { (Menit) }\end{array}$ & $\begin{array}{l}\text { Suhu } \\
\left({ }^{\circ} \mathrm{C}\right)\end{array}$ & Error & Relay & $\begin{array}{c}\text { Kelembaban } \\
(\%)\end{array}$ & $\begin{array}{c}\text { Exhaust } \\
\text { Fan }\end{array}$ \\
\hline 5 & 27 & -31 & Hidup & $60,18 \%$ & Mati \\
\hline 30 & 59 & 1 & Mati & $56,32 \%$ & Hidup \\
\hline 60 & 59 & 1 & Mati & $53,00 \%$ & Hidup \\
\hline 90 & 57 & -1 & Hidup & $50,10 \%$ & Mati \\
\hline 120 & 58 & 0 & Mati & $46,12 \%$ & Hidup \\
\hline 150 & 57 & -1 & Hidup & $42,67 \%$ & Mati \\
\hline 180 & 58 & 0 & Mati & $38,51 \%$ & Hidup \\
\hline 210 & 57 & -1 & Hidup & $34,33 \%$ & Mati \\
\hline 240 & 57 & -1 & Hidup & $30,08 \%$ & Mati \\
\hline 270 & 57 & -1 & Hidup & $26.03 \%$ & Mati \\
\hline 300 & 57 & -1 & Hidup & $22.66 \%$ & Mati \\
\hline 330 & 58 & 0 & Mati & $18.55 \%$ & Hidup \\
\hline 360 & 57 & -1 & Hidup & $15.67 \%$ & Mati \\
\hline 390 & 58 & 0 & Mati & $14.01 \%$ & Hidup \\
\hline 420 & 57 & -1 & Hidup & $13,86 \%$ & Mati \\
\hline 450 & 57 & -1 & Hidup & $12.25 \%$ & Mati \\
\hline 480 & 59 & 1 & Mati & $11.18 \%$ & Hidup \\
\hline 510 & 58 & 0 & Mati & $10.39 \%$ & Hidup \\
\hline 540 & 57 & -1 & Hidup & $9.96 \%$ & Mati \\
\hline 570 & 57 & -1 & Hidup & $9.02 \%$ & Mati \\
\hline 600 & 58 & 0 & Mati & $8.34 \%$ & Mati \\
\hline 630 & 57 & -1 & Hidup & $8.00 \%$ & Hidup \\
\hline 660 & 58 & 0 & Mati & $7.98 \%$ & Mati \\
\hline 690 & 57 & -1 & Hidup & $7.00 \%$ & Mati \\
\hline
\end{tabular}

Berdasarkan tabel 2 di atas maka dapat diketahui bahwa pengeringan pada alat ini dilakukan untuk mendapatkan kelembaban kopra sekitar 7\% dengan suhu yang relatif konstan pada $58^{\circ} \mathrm{C}$ dengan lama pengeringan yang didapatkan dengan kopra sebanyak 4 $\mathrm{Kg}$ yaitu sekitar 690 Menit. Lamanya waktu pengeringan tersebut tergantung dari seberapa besar kelembaban pada kopra tersebut, semakin lembab 
kopra maka proses pengeringan akan sedikit lebih lama dibanding dengan kopra yang tidak terlalu lembab. Berikut gambar dari kopra yang baru atau masih basah dan kopra yang telah kering . Dari perhitungan daya didapat spesifikasi alat pengering kopra sesuai tabel 3 . Tabel 3. Daya Total Alat

\begin{tabular}{|c|c|c|c|c|c|}
\hline Komponen & $\begin{array}{l}\text { Jml. } \\
\text { (bh.) }\end{array}$ & $\begin{array}{c}\text { Arus( } \\
\mathrm{mA})\end{array}$ & $\begin{array}{c}\text { Tegangan } \\
\text { input(VA } \\
\text { C) }\end{array}$ & $\begin{array}{l}\text { Daya } \\
\text { (Wat } \\
\text { t) }\end{array}$ & $\begin{array}{c}\text { Day } \\
\text { a } \\
\text { total } \\
\text { (Wa } \\
\text { tt) }\end{array}$ \\
\hline Heater & 1 & 113 & 220 & 48 & 100 \\
\hline Fan & 2 & 140 & 12 & 1,68 & $\begin{array}{c}10,0 \\
8\end{array}$ \\
\hline \multicolumn{5}{|c|}{ Daya Total } & $\begin{array}{c}110 \\
08\end{array}$ \\
\hline
\end{tabular}

\section{KESIMPULAN}

Penelitian dan pembuatan alat pengering kopra ini dapat disimpulkan sebagai berikut:

1. Kopra yang memiliki kualitas baik mempunyai range kelembaban yaitu diantara $7 \%$ - $8 \%$, untuk mencapai kelembaban tersebut di butuhkan waktu pengeringan sekitar 11 jam pada alat pengering ini.

2. Suhu maksimal yang dibutuhkan pada alat ini agar kopra mencapai kelembaban $7 \%$ dan kopra tidak rusak adalah $58^{\circ} \mathrm{C}$, respon heater untuk mencapai setpoint suhu $58^{\circ} \mathrm{C}$ tersebut dibutuhkan waktu 10 menit.
3. Rata-rata persentase error pada pembacaan suhu dan kelembaban pada sensor DHT11 sebesar $1.75 \%$.

4. Kontrol PID yang digunakan yaitu metoda zigler-nichols dengan metoda kurva reaksi, dengan metoda kurva reaksi tersebut maka didapatkan nilai $\mathrm{Kp}=24,936 \mathrm{Ti}=60$ dan $\mathrm{Td}$ $=15$.

\section{REFERENSI}

[1]Sutardi,2008.Perbandingan Pendapatan Petani Kopra Jemur dan Kopra Asap (Studi Kasus Desa peslaten Satu Kecamatan TAPAAN)

[2] Rahman,2011.Analisis Pendapatan Dan Nilai tambah kelapa menjadi kopra di desa BOLUBUNG Kecamatan Bulagi utara Kabupaten banggai kepulauan.

[3] Palungkun,1999.Analisis Nilai Tambah dan Pemasaran Kopra.

[4] Kementrian Perdagangan RI 2013.Analisis Daya Saing Kopra di Minahasa Selatan.

[5] Data primer setelah diolah,2014. Analisis Pendapatan Dan Nilai tambah kelapa menjadi kopra di desa BOLUBUNG Kecamatan Bulagi utara Kabupaten banggai kepulauan.

[6] Neprianus Siloto,2017.Perbandingan pendapatan Petani Kopra jemur dan kopra asap (Studi Kasus Desa peslaten Satu Kecamatan TAPAAN).

[7] Henderson dan Perry.1976.Pengeringan Lapis Tipis Kopra Putih Menggunakan Oven Pengering.

[8] Taib dkk,1988. Pengeringan Lapis Tipis Kopra Puth Menggunakan Oven Pengering.

[9]Welson M.Wangke 2017 Perbandingan Pendapatan Petani Kopra Jemur dan Kopra Asap,(Studi Kasus Desa peslaten Satu Kecamatan TAPAAN). 